\title{
Diode laser in the surgical treatment of inflammatory fibrous hyperplasia: Case report and literature review
}

Fernando de Oliveira Andriola ${ }^{\mathrm{a}}$, Leonardo Matos Santolim Zanettini ${ }^{\mathrm{a}}$, Ricardo Giacomini De Marco ${ }^{\mathrm{a}}$, Camila Kunz ${ }^{\mathrm{b}}$, Cássia dos Santos Machado Vaz ${ }^{\mathrm{b}}$, Rogério Miranda Pagnoncellic

\begin{abstract}
OBJECTIVE: This article presents a case of inflammatory fibrous hyperplasia (IFH) treated by diode laser surgery, as well as a review of the literature about this pathology.

CASE DESCRIPTION: A 55-year-old woman was referred to the Department of Oral and Maxillofacial Surgery, Pontifical Catholic University of Rio Grande do Sul, School of Dentistry, complaining of a discomfort on swallowing due to a soft-tissue mass in the oral cavity that had been developing for approximately 3 years. Intraoral examination revealed multiple exophytic, pedunculated lesions with a smooth surface and pinkish in color, affecting almost the entire right cheek mucosa. The lesion turned out to be a IFH by histopatology. Surgical removal of IFH of the oral mucosa using a diode laser was performed. The lesion was removed in 3 sessions. The patient reported no local symptoms after each irradiation. The clinical appearance 10 months after the last irradiation session demonstrated complete healing and no signals of recurrence.

CONCLUSION: Based on the results obtained, we can conclude that diode laser radiation contributes significantly to the advancement of oral surgery and should be considered a valuable resource for the treatment of soft-tissue lesions in the field of oral and maxillofacial surgery.
\end{abstract}

Keywords: Diode Laser; Semiconductor Lasers; Hyperplasia; Focal Epithelial Hyperplasia; Laser Therapy.

\section{Uso do laser de diodo para o tratamento cirúrgico de hiperplasia fibrosa inflamatória: relato de caso e revisão da literatura}

\section{RESUMO}

OBJETIVO: Este artigo apresenta um caso de hiperplasia fibrosa inflamatória (HFI) tratado por cirurgia a laser de diodo, bem como uma revisão da literatura sobre esta patologia.

DESCRIÇÃO DO CASO: Uma mulher de 55 anos foi encaminhada para o Departamento de Cirurgia e Traumatologia Bucomaxilofacial da Faculdade de Odontologia da Pontifícia Universidade Católica do Rio Grande do Sul, queixando-se de um desconforto durante a deglutição devido a uma massa de tecido mole na cavidade bucal com evolução de aproximadamente 3 anos. O exame intra-oral revelou múltiplas lesões exofíticas e pedunculadas com uma superfície lisa e de cor rosada, afetando quase toda a mucosa jugal direita. O exame histopatológico confirmou o diagnóstico de HFI. Foi realizada a remoção cirúrgica da HFI utilizando laser de diodo. A lesão foi removida em 3 sessões. O paciente não relatou sintomatologia dolorosa após as irradiaões. A aparência clínica 10 meses após a última sessão de irradiação demonstrou cicatrização completa e ausência de sinais de recorrência.

CONCLUSÃO: Com base nos resultados obtidos, podemos concluir que a radiação laser de diodo contribui significativamente para o avanço da cirurgia oral e deve ser considerada um recurso valioso para o tratamento de lesões de tecidos moles no campo da cirurgia oral e maxilofacial.

Palavras-chave: lasers de diodo; lasers semicondutores; hiperplasia; hiperplasia epitelial focal; terapia a laser.
aSc, Specialist in Oral and Maxillofacial Surgery, PhD Student- Oral and Maxillofacial Surgery, Dental School, Pontifícia Universidade Católica do Rio Grande do Sul (PUCRS), Porto Alegre, RS, Brazil b Specialist in Oral and Maxillofacial Surgery, Private Practice, Porto Alegre, RS, Brazil

c PhD, Full Professor, Dental School, PUCRS, Porto Alegre, RS, Brazil 


\section{INTRODUCTION}

Inflammatory fibrous hyperplasia (IFH), also termed traumatic fibroma, is a benign hyperplastic process in response to chronic low-intensity trauma in the oral cavity. IFH is composed of fibrous connective tissue and is a relatively common finding in dental practice in patients with ill-fitting dentures $[1,2]$.

Removal of the etiological factor is the indicated treatment for IFH, followed by surgical resection, which can be performed using a conventional scalpel, electric scalpel or surgical laser, without the need for a safety margin. Treatment options also include electrosurgery and cryotherapy. Because of the advantages and satisfactory results obtained with the use of lasers in dentistry, there has been increased interest in using this technique for surgical treatment of these lesions $[2,3]$. Among a number of laser systems used in dentistry and oral surgery, diode lasers currently elicit much interest due to their efficient and reliable benefits for use in oral surgical procedures as compared to other laser systems [4].

We report a case of surgical removal of IFH of the oral mucosa using a diode laser (at $808 \mathrm{~nm}$ ) and provide a review of the literature with particular emphasis on the use of laser systems in IFH.

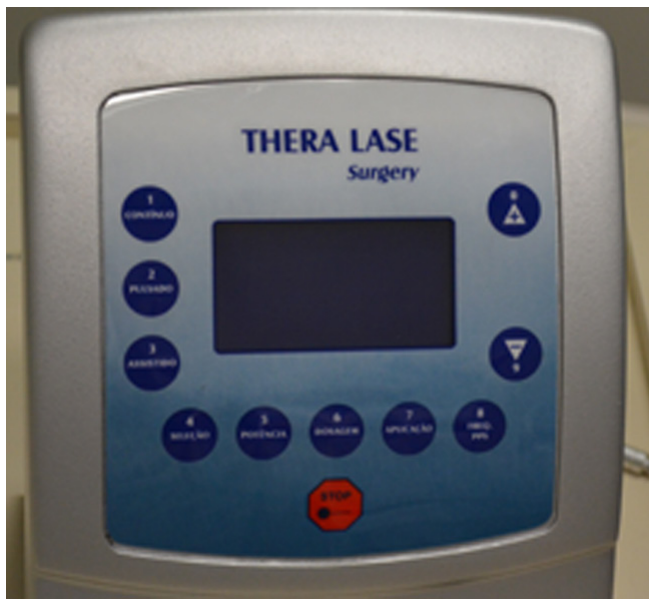

Figure 1.

Thera Lase Surgery ${ }^{\circledR}$

diode laser system.

Figure 2.

A - Initial lesion (clinical diagnosis of IFH). B - Incisional biopsy (partial) using diode laser. C - Postoperative day 2. D - Postoperative day 15.

\section{CASE REPORT}

A 55-year-old woman presented with a complaint of discomfort on swallowing due to a soft-tissue mass in the oral cavity that had been developing for approximately 3 years. Intraoral examination revealed multiple exophytic, pedunculated lesions with a smooth surface and pinkish in color, affecting almost the entire right cheek mucosa. Based on clinical features and the natural history of the lesion, the initial clinical diagnosis was IFH.

The patient was referred to the Department of Oral and Maxillofacial Surgery of the institution for diode laser treatment (Thera Lase Surgery ${ }^{\circledR}$; DMC, São Carlos, SP, Brazil) (Figure 1). Laser energy was delivered to the tissue in contact mode with movements along the peduncle, without penetrating the muscle fibers. The diode laser is designed to emit high-energy infrared light at a wavelength of 808 $\mathrm{nm}( \pm 10 \mathrm{~nm})$ and power of $4.5 \mathrm{~W}( \pm 20 \%)$. The diameter of the optical fiber used in this case was $600 \mu \mathrm{m}$. No cooling technique was used on irradiated tissues $[5,6]$.

The lesion was removed in 3 sessions. The laser power was set at $3800 \mathrm{~mW}$ for the first 2 sessions and $3200 \mathrm{~mW}$ for the last session and delivered in continuous mode at an average energy of $400 \mathrm{~J}$ per session. The mean radiation dose was $2.5 \mathrm{~W} / \mathrm{cm}^{2}[6]$.

For incisional biopsy (Figure 2), local anesthesia was achieved with infiltration of $1.8 \mathrm{~mL}$ of $4 \%$ articaine with 1:100,000 epinephrine (DFL, Rio de Janeiro, RJ, Brazil). One of the exophytic lesions was removed at the base.

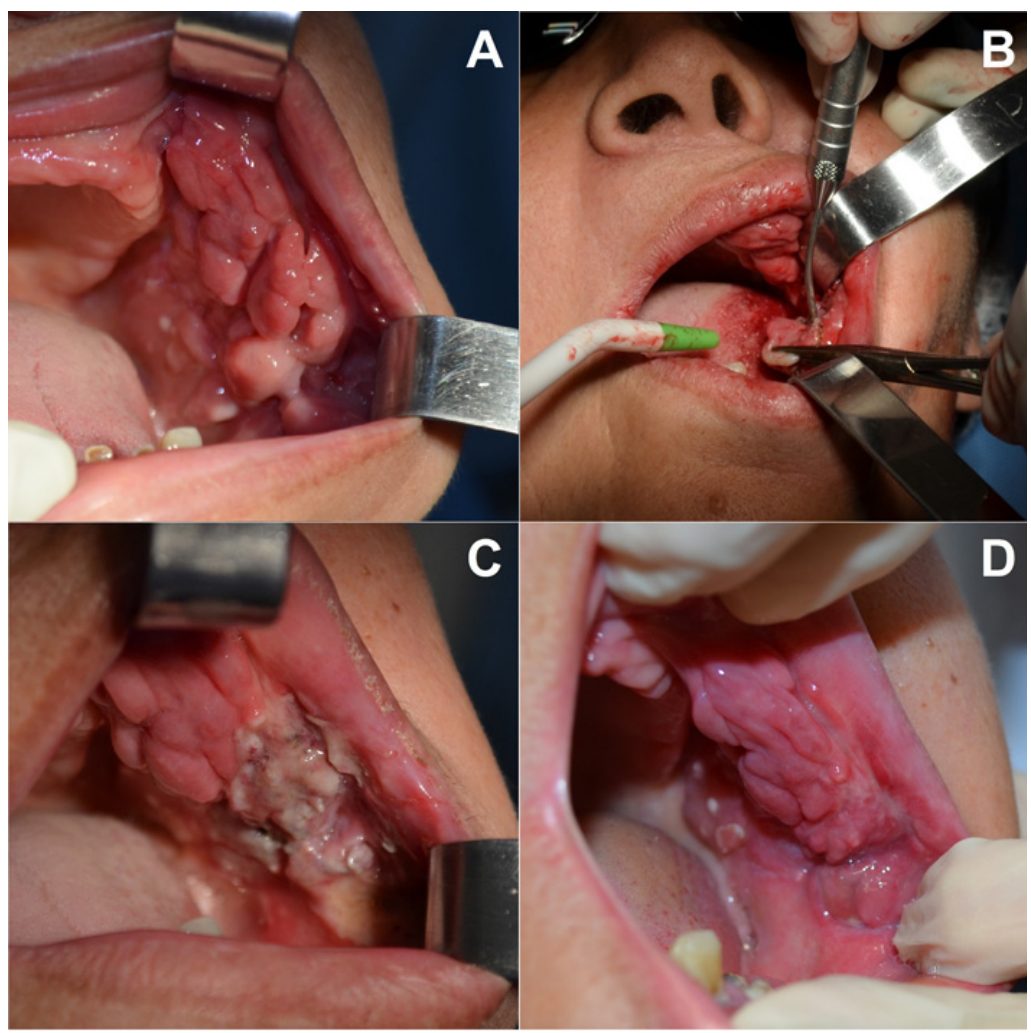


The surgical specimen was fixed in 10\% formalin and sent for anatomopathological examination. Histopathology confirmed the diagnosis of IFH (Figure 3).

Two weeks after the first procedure to partially remove the IFH, the patient had a session of low-level laser therapy to accelerate the healing process. Thirty days after the first irradiation session, the patient underwent further vaporization procedure to remove the IFH (Figure 4). Also using the diode laser, the lesion was completely removed in the third session, which occurred 90 days after the previous irradiation session (Figure 5).
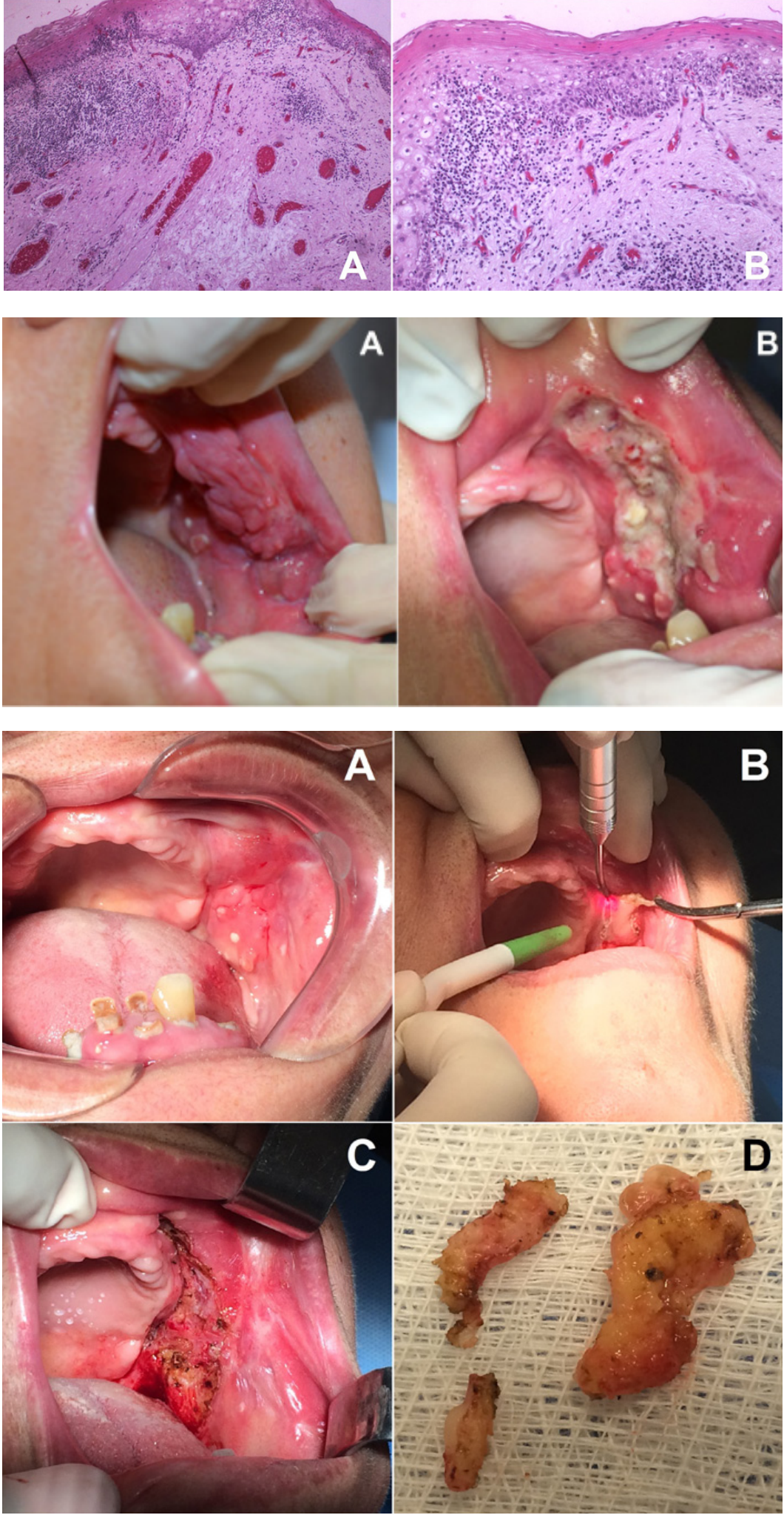

Figure 3.

A - Histological section showing parakeratinized stratified squamous epithelium irregular hyperplasia of epithelial crests, chronic inflammatory infiltrate, and hyperemia (hematoxylin-eosin [HE], x40).

B - Fibrous connective tissue with collagen fiber hyperplasia, hydropic degeneration of epithelial cells, and chronic inflammatory infiltrate composed mainly of lymphocytes and macrophages (HE, x100).

\section{Figure 4.}

A - IFH appearance before the second irradiation session with diode laser for lesion removal (30 days after the first intervention).

B - Postoperative day 2 (after the second irradiation session).

\section{Figure 5.}

A - IFH appearance before the last surgical procedure.

B - Vaporization of the remaining lesion with diode laser

C - Appearance of the vaporized tissue in the immediate postoperative period.

D - Surgical specimens removed in the last session. 
Postoperative care included application of ice to the affected area, elevation of the head of the bed, and administration of analgesics (acetaminophen $750 \mathrm{mg}$, one capsule every 6 hours in case of pain), anti-inflammatory drugs (ibuprofen $600 \mathrm{mg}$, one tablet every 12 hours for 3 days) and antibiotics (amoxicillin $500 \mathrm{mg}$, one capsule every 8 hours for 7 days). Seven days later, at the first follow-up visit, the patient reported no local symptoms. At the end of irradiation sessions, the patient was referred for tooth extraction and subsequent oral rehabilitation. Postoperative appearance after 10 months of the third irradiation session for IFH removal showed no signals of recurrence (Figure 6).

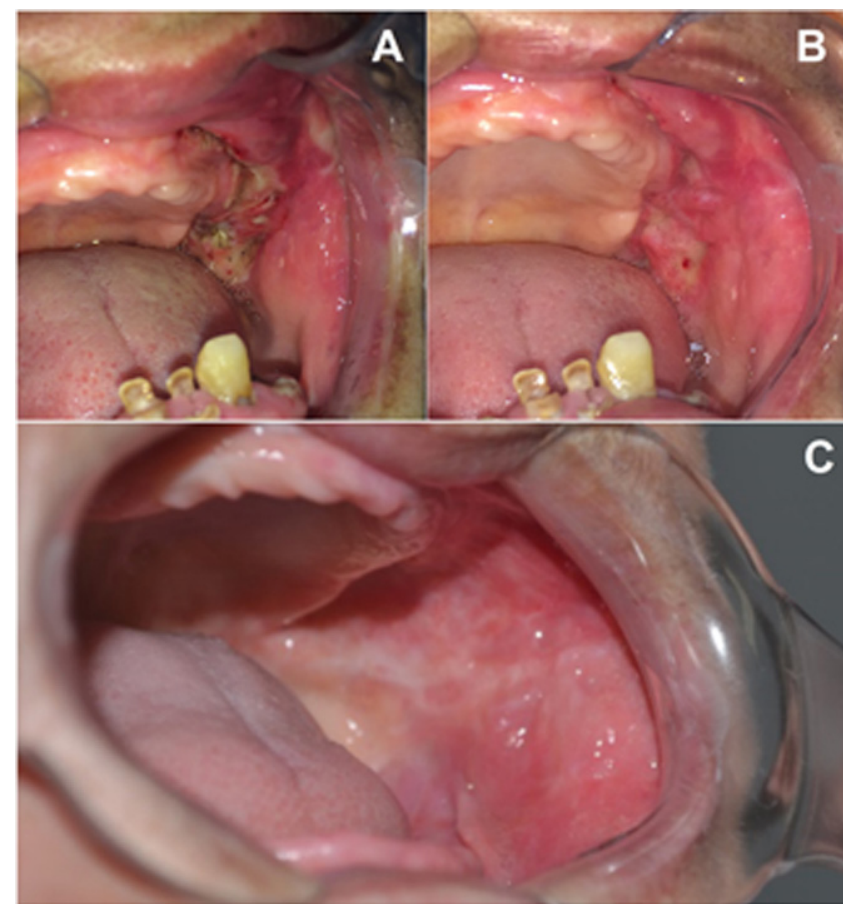

Figure 6. Postoperative appearance at A - 48 hours and B - 7 days after the third irradiation session for IFH removal. C - Clinical appearance 10 months after the last irradiation session for IFH removal, with complete healing of the wound bed.

Written consent was obtained from the patient to publish this case report. The study was approved by the Research Ethics Committee of the institution.

\section{DISCUSSION}

IFH presents clinically as a lesion with raised borders or an exophytic lesion that can be either soft or firm to palpation. These lesions have a slow growth, which may be sessile or pedunculated, with a smooth or verrucous surface and normal mucosal or erythematous color; most patients are asymptomatic. On histopathological examination, lesions are characterized by the presence of stratified squamous epithelium, which may or may not have a keratin layer, surrounded by hyperplastic fibrous connective tissue, with aggregates of chronic inflammatory cells and a large number of collagen fibers and blood vessels. Salivary glands may also be involved $[1,2]$.

IFH commonly occurs in the oral cavity, with a preference for the gingiva, cheek mucosa, lips and palate. Ill-fitting dentures, diastema, sharp-edged teeth, smoking, iatrogenic complications and poor oral hygiene are the main etiological factors [7-11]. In the case reported here, the patient did not wear dentures, and poor hygiene, associated with the sharp edges of the remaining teeth, was the probable etiological factor.

IFH is more prevalent in women than in men, and the predominant lesion site is the buccal sulcus. Although IFH can occur at any age, it has a peak incidence in the fifth decade of life $[1,7,9]$.

Surgical resection is the treatment of choice for IFH, often using a small safety margin. In addition, removal of the etiological factor ensures successful treatment. The diagnosis should always be confirmed by biopsy and histopathology, and the differential diagnosis should include lesions such as lipofibroma, neurofibroma, and intraoral minor salivary gland tumors, among others [12].

Dentistry, an area which throughout history has searched for techniques to minimize pain, stimulate repair and healing and reduce edema, has recognized laser therapy as a valuable alternative to traditional techniques. Highpower laser radiation can be used for several soft- and hard-tissue surgical procedures, including clinical crown lengthening, gingivoplasty, incision for abscess drainage, biopsy, hemangiomas, and hemostasis $[1,13]$.

Incident laser radiation must be absorbed by tissue to produce an effect on the target tissue. In some situations, heat buildup may occur at the irradiation site, which may or may not be therapeutically useful. Light energy is emitted at different wavelengths and each tissue type has specific absorption features, which are closely related to the wavelength of the emitted light. Therefore, the laser type and wavelength must be chosen in a way that ensures that the laser wavelength will be efficiently absorbed by the target tissue. In addition, the target tissue must be exposed to laser energy to produce the desired thermal effect. Different types of laser (argon, $\mathrm{CO}_{2}$, neodymium-YAG, etc.) emit radiant energy of different wavelengths and should therefore only be used in specific types of tissue $[14,15]$.

When laser radiation is applied to soft tissues for incision and hemostasis, it will be absorbed by pigment and blood, resulting in three consequences for the tissue: vaporization, coagulation, and necrosis. The extent of these effects varies according to the energy dose and irradiation spot. Higher energy doses effect a greater vaporization rate and produce deeper incisions. Thus, an advantage is the reduction in the amount of microorganisms and bleeding [14, 15].

The advantages of using high-power laser for intraoral soft-tissue surgery include hemostasis, shorter operative time, no suture, and reduced trauma, edema, scar, pain and postoperative infection rates (associated with the use of lowlevel laser therapy) [1-5]. High-power laser radiation is also indicated for removal of malignant lesions, as it promotes 
immediate sealing of blood and lymphatic vessels, thus reducing the risk of metastasis $[10,14]$.

Diode laser systems are compact, portable, efficient, reliable and easy to use. They can be used in continuous, pulsed or micropulsed mode and delivered to the tissue in either contact or noncontact mode, which is decided according to the clinical approach chosen. Diode lasers have wavelengths ranging from 810 to $980 \mathrm{~nm}$. Based on the photothermal effects of diode laser radiation, oral mucosal lesions may be removed by excision or vaporization [4].

The diode laser has been approved by the Food and Drug Administration (FDA) for use in oral surgery. The surgical wound created by diode laser radiation is extremely superficial. In addition, only a small number of chemical mediators of inflammation are released, associated with reduced inflammatory response compared to conventional surgery [5]. In the immediate postoperative period, the wound shows crust formation (dry in skin, wet in mucosa) and there is inorganic tissue or even charred tissue with bright yellow or whitish areas [11].

According to Angiero et al. [15], there is considerable controversy about the use of diode laser radiation for biopsy due to potential thermal tissue damage, which may alter the edges of the specimen and hinder the histopathological diagnosis. This disadvantage was also mentioned by Azma et al. [4], and the same drawback is shared by other laser types. However, studies have demonstrated that specimens obtained with a diode laser system have good histological readability and that specimen changes (such as thermal damage) can be minimized by the laser features and settings, such as wavelength, emission mode, type of optical fiber, and tissue affinity $[15,16]$.

Low-level laser therapy was used in the case described here due to its ability to promote biostimulatory effects on the repair of peripheral nerves and to assist in processes such as revascularization, cell proliferation, and collagen synthesis. In addition, it has analgesic and anti-inflammatory effects and reduces postoperative edema [17-20].

Monteiro et al. [2] reported that $\mathrm{CO}_{2}$ laser radiation has many advantages over conventional surgery, such as high precision, hemostasis without the need for sutures, and reduced risk of postoperative infection - advantages that are also shared by diode laser radiation. Camilotti et al. [5] and Jasper et al. [6] added other advantages to the use of diode laser radiation, including shorter operative time, reduced amount of local anesthetic, minimal or no need for suturing, excellent hemostatic effect, and minimal postoperative pain and edema [21].

Falcão et al. [9] stated that excisional biopsy is the preferred treatment for IFH, followed by insertion of new dentures or definitive rehabilitation and oral hygiene guidance. The treatment used in the present study followed the therapeutic approach recommended by these authors.

Finally, successful treatment of extensive lesions of IFH requires, in addition to the surgical removal of lesions, proper identification and elimination of the etiological factor. The use of diode laser radiation for the removal of hyperplastic tissue allows adequate functional recovery in these patients and appears to be an excellent option for the treatment of soft-tissue lesions in the oral cavity in view of its peri- and postoperative advantages.

Based on the results obtained, we can conclude that diode laser radiation contributes significantly to the advancement of oral surgery and should be considered a valuable resource for the treatment of soft-tissue lesions in the field of oral and maxillofacial surgery.

\section{REFERENCES}

1. Monteiro LS, Mouzinho J, Azevedo A, Câmara MI, Martins MA, La Fuente JM. Treatment of epulis fissuratum with carbon dioxide laser in a patient with antithrombotic medication. Braz Dent J 2012 [cited 2017 Jul 18];23: 77-81. Available at: http://www.scielo.br/pdf/bdj/v23n1/v23n1a14.pdf

2. Monteiro LS, Mouzinho J, Martins MA. Treatment of denture induced fibrous hyperplasia with carbon dioxide laser. Int J Oral Maxillofac Pathol 2012 [cited 2017 Jul 18];3:34-7. Available at: http://journalgateway.com/ ijomp/article/view/245/541

3. Eliades A, Stavrianos C, Kokkas A, Kafas P, Nazaroglou I. 808 nm diode laser in oral surgery: a case report of laser removal of fibroma. Res J Med Sci 2010 [cited 2017 Jul 24];4:175-8. Available at: http://www. medwelljournals.com/abstract/?doi=rjmsci.2010.175.178

4. Azma E, Safavi N. Diode laser application in soft tissue oral surgery. J Lasers Med Sci 2013 [cited 2017 Jul 24];4:206-11. Available at: https:// www.ncbi.nlm.nih.gov/pmc/articles/PMC4282004/

5. Camilotti RS, Jasper J, Ferreira TB, Antonini F, Poli VD, Pagnoncelli $\mathrm{RM}$. Resection of gingival fibromatosis with high-power laser. J Dent Child (Chic) 2015 [cited 2017 Jul 24];82:47-52. Available at: http:// web.b.ebscohost.com/ehost/pdfviewer/pdfviewer?vid=1\&sid=95bcc21bb49c-4f66-885f-4046f4dd7c78\%40sessionmgr102

6. Jasper J, Camilotti RS, Pagnoncelli RM, Poli VD, da Silveira Gerzson A, Gavin Zakszeski AM. Treatment of lip hemangioma using forced dehydration with induced photocoagulation via diode laser: report of three cases. Oral Surg Oral Med Oral Pathol Oral Radiol 2015 [cited 2017 Jul 24];119:e89-94. Available at: https://doi.org/10.1016/j.000o.2014.03.005

7. Coelho CM, Zucoloto S, Lopes RA. Denture-induced fibrous inflammatory hyperplasia: a retrospective study in a school of dentistry. Int J Prosthodont 2000[cited 2017 Jul 24]:148-51. Available at: http://web.a.ebscohost. com/ehost/pdfviewer/pdfviewer?vid=1\&sid=0d510481-5562-4dce-96a69bd572bf0d96\%40sessionmgr4006

8. Paes-Junior TJ, Cavalcanti SCM, Nascimento DFF, Anzaloni Saavedra GDSF, Kimpara ET, Borges ALS. CO2 laser surgery and prosthetic management for the treatment of Epulis Fissuratum. ISRN Dent 2011 [cited 2017 Jul 24]. Available at: https://www.hindawi.com/journals/ isrn/2011/282361/

9. Falcão AFP, Lamberti PLR, Lorens FGL, de Lacerda JA, Nascimento BC. Hiperplasia fibrosa inflamatória: relato de caso e revisão de literatura. Rev Ciên Med Biol. 2009;8:230-6.

10. Kuhn-Dall'Magro A, Lauxen JR, dos Santos R, Pauletti RN, Dall'Magro E. Laser cirúrgico no tratamento de hiperplasia fibrosa. RPF. 2013;18: 206-10.

11. Pedron IG, Carnava TG, Utumi ER, Moreira LA, Jorge WA. Hiperplasia fibrosa causada por prótese: remoção cirúrgica com laser Nd: YAP. Rev Clin Pesq Odontol. 2007;3:51-6

12. Coelho CMP, Souza YTCS, Daré AMZ. Denture-related oral mucosal lesions in a Brazilian school of dentistry. J Oral Rehabil 2004 [cited 2017 Jul 24];31:1135-9. Available at: http://web.b.ebscohost.com/ ehost/pdfviewer/pdfviewer?vid=1\&sid=d764e7f5-a99c-4478-a5ce8dfb7fd7b110\%40sessionmgr120

13. da Silva DL, Abreu MER, Pagnoncelli RM. Laser de Nd: YAG no tratamento de hemangioma. Rev Port Estomatol Cir Maxilofac 2008 [cited 2017 Jul 24];49:105-9. Available at: https://doi.org/10.1016/S1646-2890(08)70043-8

14. Kreisner PE, Viegas VN, Pereira ACL, Pagnoncelli RM. Excisão cirúrgica de hemangioma labial com laser de Nd: YAG. Rev Fac Odont 2004 [cited 2017 Jul 24];45:39-42. Available at: http://revodonto.bvsalud.org/pdf/rfo/ v18n2/a15v18n2.pdf

15. Angiero F, Parma L, Crippa R, Benedicenti S. Diode laser ( 808 nm) applied to oral soft tissue lesions: a retrospective study to assess histopathological diagnosis and evaluate physical damage. Lasers Med Sci 2012 [cited 2017 Jul 24];27:383-388. Available at: https://link-springer-com.ez94. periodicos.capes.gov.br/article/10.1007/s10103-011-0900-7 
16. Desiate A, Cantore S. Tullo D, Profeta G, Grassi FR, Ballini A. 980 nm diode lasers in oral and facial practice: current state of the science and art. Int J Med Sci 2009 [cited 2017 Jul 24];6:358-364. Available at: https://www. ncbi.nlm.nih.gov/pmc/articles/PMC2786991/

17. Paes JV, Valiati R, de Sá V, Paes FL, de Moraes JFD, Dedavid BA, et al. Effects of laser therapy on morselized bone Allograft incorporation laser therapy and bone grafts Incorporation. J Surg Transplant Sci. 2004;2: 1004.

18. Batista JD, Zanetta-Barbosa D, Cardoso SV, Dechichi P, Rocha FS, Pagnoncelli RM. Effect of low-level laser therapy on repair of the bone compromised by radiotherapy. Lasers Med Sci 2014 [cited 2017 Jul 24];29:1913-1918. Available at: https://link-springer-com.ez94.periodicos. capes.gov.br/article/10.1007/s10103-014-1602-8
19. Buchaim RL, Andreo JC, Barraviera B, Ferreira Junior RS, Buchaim DV, Rosa Junior GM, de Oliveira AL, de Castro Rodrigues A. Effect of low-level laser therapy (LLLT) on peripheral nerve regeneration using fibrin glue derived from snake venom. Injury 2015 [cited 2017 Jul 24];46:655-660. Available at: https://doi.org/10.1016/j.injury.2015.01.031

20. Carroll JD, Milward MR, Cooper PR, Hadis M, Palin WM. Developments in low level light therapy (LLLT) for dentistry. Dent Mater. 2014 [cited $2017 \mathrm{Jul}$ 24];30:465-475. Available at: https://doi.org/10.1016/j.dental.2014.02.006

21. Walsh LJ. The current status of laser applications in dentistry. Aust Dent J. 2003:48:146-155.

$\xi$ 